\title{
Taking the helm at the family operation under the watchful eye of the predecessor: Succession in European horticulture and
} agriculture

\author{
S. Mair ${ }^{1}$ and M. Rombach ${ }^{2}$ \\ ${ }^{1}$ Technical University of Munich, Chair Group of Economics of Horticulture and Landscaping, Freising, Germany \\ ${ }^{2}$ Lincoln University, Land Management and Systems, Lincoln, Christchurch, New Zealand
}

\begin{abstract}
Summary
The present case study investigated the intra family succession process in agricultural and horticultural enterprises from a successor perspective. The study shows educational and relational similarities in different European countries. The study follows a qualitative research approach and aims to provide a detailed picture of succession processes, comparing managers with different areas of specialization. The results show that a successful succession process requires organizational and analytical skills, advanced personal skills and attitudes such as patience, calm, and self-confidence, as well as knowledge-based skills in communication, management, finance, and law on the part of all involved. In the process, successors must cope with relational conflicts such as sibling rivalry or shadows of the previous generation. Open communication, physical distance, role definition and the acknowledgement of their experience by the predecessor and, if necessary, consulting can support addressing these issues. The relationship findings corroborate work-family border theory.
\end{abstract}

\section{Keywords}

instrumental case study, inductive qualitative content analysis, relational conflicts, skills and knowledge requirements

\section{Introduction}

In 2013, in the EU 28 there were 10.8 million farms of which approximately $96 \%$ were family farms. A family farm is a farm under family management where family workers provide at least $50 \%$ of the regular labor. These family farms manage 120 million ha agricultural land, which is $68 \%$ of the total agricultural land used for cultivation ${ }^{\text {a }}$ in the European Union (Eurostat, 2016). European family farms are currently facing a number of challenges, for instance the development of farms towards larger and more specialized operations (Howley et al., 2012). Agricultural family businesses struggle to find the necessary workforce to maintain their farm and in addition raise successors, which allows for continued existence and development of the farms (Lobley et al., 2016; Burton and Fischer, 2015). This trend is also reflected in so-

\footnotetext{
${ }^{a}$ Agricultural land used for cultivation includes also specialty crop production such as fruit, vegetable and ornamental production.
}

\section{Significance of this study}

What is already known on this subject?

- Succession is usually researched from a predecessor's perspective. Furthermore, succession studies are usually dedicated to individual countries only.

\section{What are the new findings?}

- The study compares different European countries and focuses on the successor's perspective. The study connects relational conflict to work-family border theory and classifies skills required in the succession process.

\section{What is the expected impact on horticulture?}

- Succession is a recent topic in European horticulture. Within the sector there are problems to find suitable successors. The paper identifies different types of conflicts occurring in a horticultural and agricultural succession process, as well as skills and knowledge required for a successful succession process.

cio-demographic profiles of farm managers. Around 58\% of the 10.7 million active farm managers are 55-65 years old, and managers in the age range of 25-35 years account for only $6.6 \%$ of all managers (Eurostat, 2016).

In European countries, the family farm is still the most common form of ownership, where succession proceeds intergenerational (Leonard et al., 2017). Within intergenerational succession, timing is a crucial factor: if a predecessor decides to retire too early, the farm may be left to an inexperienced successor who cannot withstand competitive pressures from more efficient farms. If retirement occurs too late, the family farm may be left without a successor since all potential successors may have left, for non-agricultural employment (Potter and Lobley, 1996; Riley, 2016).

Farm succession is complex; it includes several sub-processes such as retirement (current farm manager ceases the active managerial control), inheritance (legal transfer of ownership) and succession (transfer of the managerial control) (Potter and Lobley, 1996). It is a process that takes place over an extended period (Steiger et al., 2011), and is accompanied by farm family members and consultants who provide legal and financial advice (Leonard et al., 2017). Planning, control, and management are essential, because the process is not necessarily smooth and continuity in the farm's operation needs to be secured (Steiger et al., 2011; Leonard et al., 2017). 


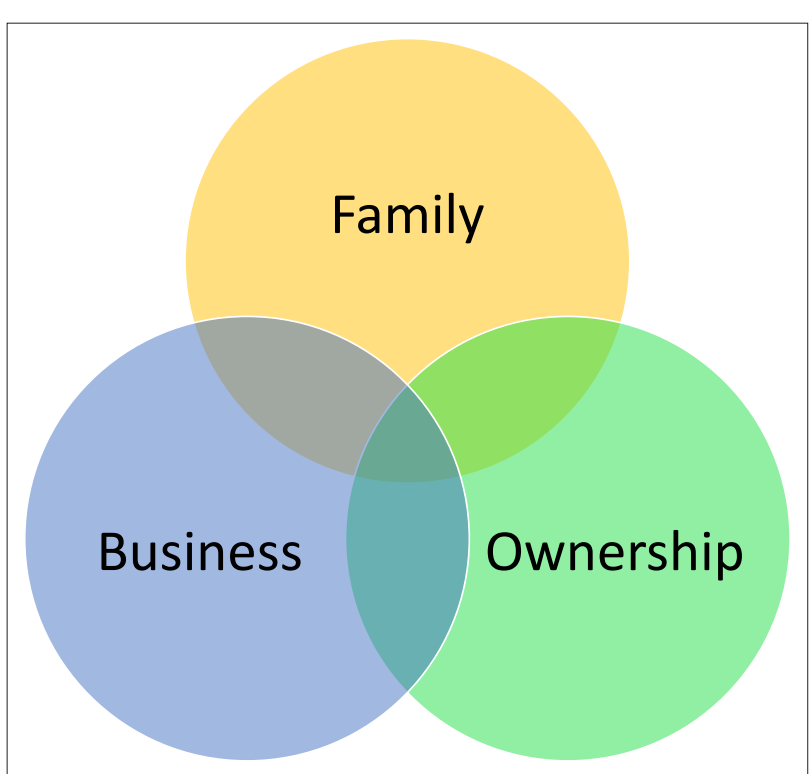

FiguRE 1. Three-circle model. Source: Tagiuri and Davis (1982).

The management of the succession process is difficult, as predecessors have to accept the end of their active involvement as head of the farm and are often unwilling to select a successor (Gagnè et al., 2011; Chiswell, 2014, 2018), which can lead to conflict. Prior literature on succession in horticulture and agriculture and other disciplines presented post-succession conflicts (Harvey and Evans, 1995; Chua et al., 2003; Collins et al., 2016; Urmans et al., 2018), and succession models such as the three-circle model, and the role adjustment model (Gersick et al., 1997; Handler, 1989; Mair and Bitsch, 2018). The three-circle model is widely known and used by extension agents and scholars in agriculture and related fields as horticulture (see Figure 1).

The model was developed by Tagiuri and Davis (1992) and aims to understand three main characteristics of a family business: business, family and ownership. The model shows how these characteristics are interconnected, and seven relevant groups are presented. The groups interact with one and another and some individuals take on multiple roles (Klein, 2000). The group interaction affects business performance, the family and the entire family business system. The groups have their own specific priorities, goals and dynamics (Tagiuri and Davis, 1992). The model concludes that respect and integration of the different priorities, goals and dynamics are necessary to direct the family business system (Sharma, 2004). The family business system, whether it is successful or not, depends on the functioning and mutual support of each of these groups (Bizri, 2016).

In a similar manner, work-family border theory aims to explain how people manage and negotiate their work and family environment. The theory considers work and family as two areas with borders that need to be balanced. These borders are not necessarily distinct, because the areas are overlapping and influence each other (Clark, 2000). As they are however different in their purposes and cultures, the business environment and the living environment can be compared to two different countries with differences in language, rules, norms, differences in what constitutes acceptable behavior, and differences in how to accomplish tasks (Greenhaus et al., 2003). The theory views people as border-crossers who move between both areas. In cases where language, rules, values, and norms are similar, the balance of professional and personal goals, expectations, as well as lifestyle, requires only minor adjustment (Clark, 2000). In cases where the differences are large, balancing both areas is more difficult. The adjustment of both, private and professional environment, leads to satisfaction and conflict minimization, as the "border crosser" performs the respective role in the given environment in a satisfactory manner, and learns how to appropriately function in each environmental situation (Kreiner et al., 2009).

Other papers view succession as a process influenced by family and business factors (Burton and Fischer, 2015). Further branches of literature discussed the perspective of the predecessor or focused on specific countries (Andersson et al., 2002; Cadieux et al., 2002; Dalpiaz et al., 2014; Nuthall and Old, 2017). Country comparisons are rare (Burton and Fisher, 2015; Lobley et al., 2016) and few studies focus on successors' challenges in the process.

Therefore the present study aims to fill this research gap, analyzing and explaining the horticultural as well agricultural succession process from a successor's perspective in five European countries (Germany, Italy, Spain, Slovenia, and the Czech Republic). As the general economic situation is different in the chosen countries, differences in the succession process can be expected. In contrast to Germany with low youth unemployment, in the Czech Republic and Slovenia youth unemployment rate ranges from $6-14 \%$, in Italy and Spain youth unemployment is significantly higher and ranges in between 30-35\% (Eurostat, 2019). In cases were the future of the business is not as promising, or there are only few alternative options due to high unemployment rates (De Massis et al., 2008), the economic conditions may affect the successor's willingness to take over the business (Nuthall and Old, 2017). Legal issues may also influence the succession (Chalus-Sauvannet et al., 2016). However problems are expected to be similar within the European Union, since laws are adjusting over time. Further, the study explores lessons learned from the succession process as well as skills and training needs for the succession process, as these are personal skills of the successor which are not yet widely studied but essential to successfully complete a succession process.

\section{Literature review}

A successful intergenerational succession involves challenges and chances for the successor. These chances and challenges are commonly of relational nature, related to the successor and his or her competence, unexpected events, and finance (Barach and Ganitsky, 1995; De Massis et al., 2008). Further there are business specific and process specific factors, which relate to changes occurring in the business environment and within the business (Brandth and Overrein, 2013; Burton and Fischer, 2015).

The relationship with the successor is among the top priorities of the predecessor and there is a need for communication of goals between them in a timely manner. The relationship is challenging if the successor has a low priority for the needs of the predecessor and there is no clear communication. Communication between the two parties should include failures and successes, as the predecessor can create attention, pride, and the desire for the successor to be involved in the business and eventually continue it (Barach and Ganitsky, 1995). The predecessor should ideally serve as a leader and role model (De Massis et al., 2008), and share experiences with the successor (Davis et al., 2010).

On the contrary, if information sharing is unbalanced in terms of failures and successes and achievements are hard- 
ly recognized, the successor may remain unmotivated to continue the business or as a consequence even act rebellious (Landsberg, 1988; Barach and Ganitsky, 1995). Within their relationship, predecessor and successor should strive for win-win solutions and avoid a clash of egos. Predecessor and successor need to share their expectations towards each other and discuss their reasoning. This allows developing agreement regarding company policies and adjusting to each other's needs. In cases when expectations are not communicated, successor and predecessor remain distant and have frequent misunderstandings and conflicts (Barach and Ganitsky, 1995; Samei and Feyzbakhsh, 2015). Both parties should strictly separate responsibilities and tasks to overcome tension, and to make it more likely that the succession process can be completed (Leiß and Zehrer, 2018; Umans et al., 2018).

As the predecessor can serve as a role model for the successor, the personal characteristics and behaviors of the predecessor can affect the successor's actions (Lee et al., 2003). In positive cases, the predecessor encourages participation, sets an example of work-life balance, and is receptive to other points of view, delegates tasks, and has trust in the successor and the employees. In negative cases, the successor imitates strict control, minimal trust, and has problems to delegate (Boyar et al., 2005; Kidwell et al., 2018).

In addition to the relationship between successor and predecessor, the successor's actual and perceived competencies are factors in the succession process (Cabrera-Suárez et al., 2018). The successor's attitudes, skills, and performance convince the predecessor either that a suitable successor has been chosen or the successor is unsuitable (Barach et al., 1988; Landsberg, 1999). The successor must show the ability to fulfill the predecessor's expectations, business goals, and lead the family farm to progress. For this purpose, the successor must meet the requirements of the predecessor with regard to qualifications (Breton-Miller et al., 2004), and prove worthiness through daily work. In this way, the successor earns credibility and legitimacy. This is also applicable to other family members, employees, and other stakeholders within the family (Eddleston and Kellermanns, 2007). In cases when the successor is perceived weak or incapable, and is unable to gain trust within the family and from stakeholders, the successor will lack confidence and act defensively (Rousseau et al., 2019). The successor may even perceive rivalries with other executives in the family business that hold power (Barach and Ganitsky, 1995).

Equally important is the successor's commitment to the family business (Dhaenens et al., 2018). If the successor joins the firm voluntarily, feels welcomed, wanted and trusted, and not pressed into the successor role, the commitment will be very strong (Sharma and Irving, 2005). In contrast, it will be weak, if the successor feels compelled to take over the family farm. The successor may not strive for the best and feels deprived of other career opportunities (Calabrò et al., 2018; Waldkirch et al., 2018). When there are other potential successors within the family, the role of the potential chosen successor needs to be accepted and respected by the other family members (Friedmann, 1991; Joshi et al., 2018; Byrne et al., 2018). Otherwise, there are power imbalances within the family business, and there may even be no progress in the succession process due to fear, aversion, and envy (Avloniti et al., 2014)

Further issues that can negatively affect succession are divorce (Welter et al., 2017), the birth of new children from a new partner, and unexpected losses or illnesses in the family environment (De Massis et al., 2008; Harrington and Strike, 2018). All events can emotionally affect the successor, and may impede the succession. Divorce may also affect ownership within the family business (Bjuggren and Sund, 2014; Lockamy et al., 2016). Children from different partnerships have long-term effects on succession because they can lead to unexpected changes or complications (De Massis et al., 2008; Fahed and Zakka, 2016). The unexpected absence or loss of a family member, in the worst case, the predecessor, is an extremely challenging situation for the successor, as it may conclude the succession process too early, when the successor is not ready, or prevent succession. It may lead to changes in goals, succession intentions, or direct the succession towards a different successor (Dudek, 2016).

A successful succession process usually ends with a change in ownership. The inheritance and the change in ownership are transactions, which require tax payments (Michel and Kammerlander, 2015). These payments could exceed the successor's financial resources (Harrington and Strike, 2018). Banks or other external sources could provide funding; however, they will decide whether debts are too high, and whether the successor needs to liquidate assets. Selling shares of the family farms privately to raise funds is another option, but the increase of external control could be an impeding factor (De Massis et al., 2008). Another challenging financial aspect may occur if the chosen successor is not the only heir (Gherardi and Perrotta, 2016), and the successor who takes over the family business legally is unable to pay off heirs leaving the family business (Chalus-Sauvannet et al., 2016). Analogous to the tax situation, the successor in this case may have to accept outside capital, which leads to a decrease in control of the family business. Such situations may lead to the succession becoming unattractive (De Massis et al., 2008).

In addition to finance, context specific factors that lead to changes in the business environment can be challenging in the succession process (De Massis et al., 2008). Market shifts, such as increased competition, decreased market shares, leading to decreased sales may affect the prospects of the family business and lead to changes in the availability of the successor (De Massis et al., 2008). Another challenge is establishing relationships with customers and suppliers of the family business. Customers and suppliers may trust the predecessor with whom they have developed a business relationship. They may request that the predecessor continues to handle their business matters, which can lead to tensions (De Massis et al., 2008).

The presented challenges and chances that a successor can face in the succession process, indicate that a wide range of lessons learned are possible. Succession literature does not provide extensive information on this aspect, even though the lessons learned from the process are of high relevance for best practice recommendations and for potential successors. Successor will act as future predecessors and may want to prevent conflict and instead sufficiently prepare the new successor. Therefore training and skills are required to manage the process successfully.

Deducing from the expectations towards successors and their competencies, an agribusiness management background is required, which involves technical knowledge and engineering skills, production specific knowledge, knowledge of supply chains, business knowledge such as book keeping, marketing and sales, as well as written and oral communication skills (Boland, 2001; Barnard et al., 2016; Fausti et al., 2018). Specifically for the succession process, 

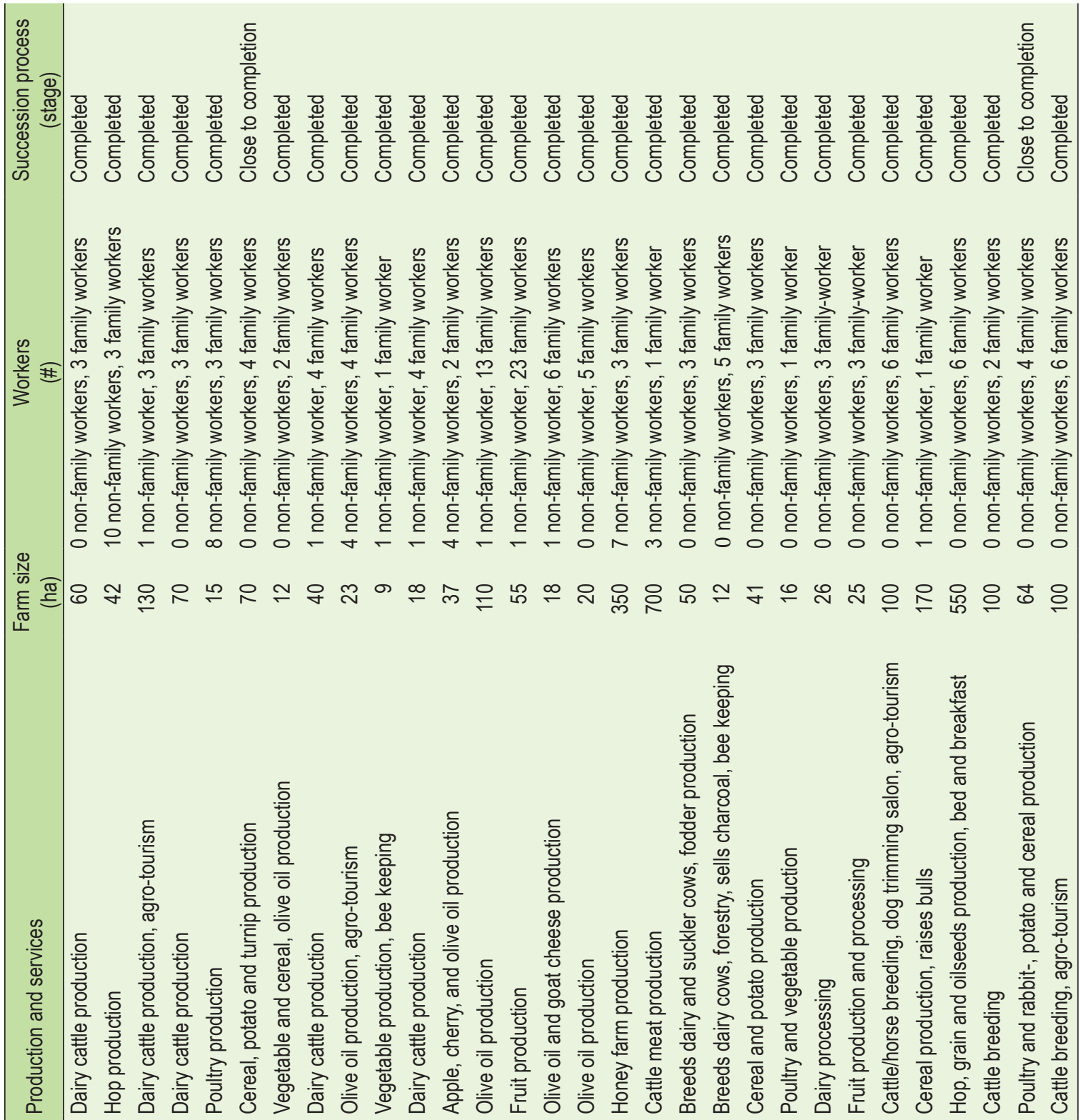

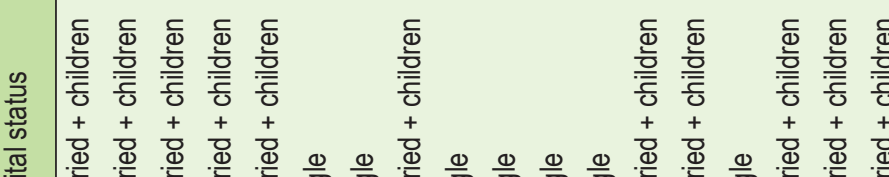
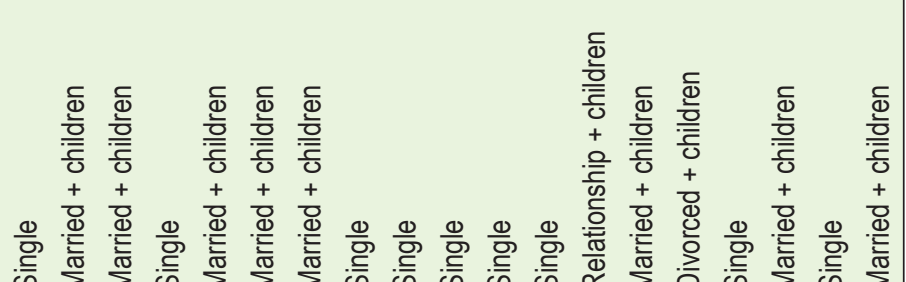

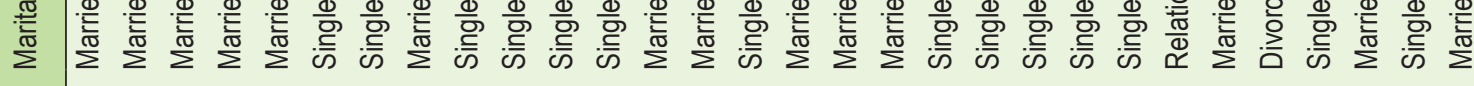

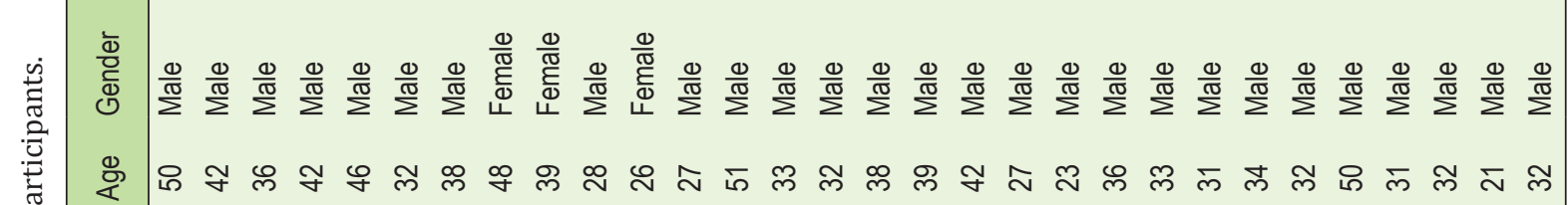

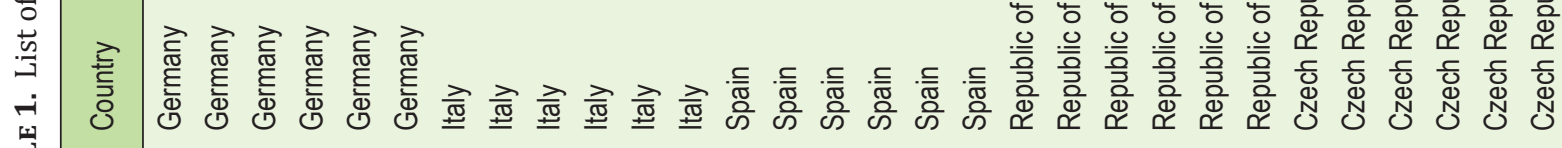
- .

ब्ग

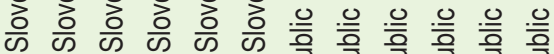
兽 
interpersonal and communication skills are required, as well as legal and financial knowledge. Literature recommends that successor and predecessor seek the necessary advice from external consultants or other trusted advisors who provide support with succession management and guidelines or procedures to follow, regular discussion, assistance in the preparation of agreements and contracts (Michel and Kammerlander, 2015; Strike et al., 2018).

\section{Methods}

A multiple, qualitative case study approach is used for this study, as the approach allows generating an in-depth understanding in a real-life context (Mugera and Bitsch, 2005). Case studies regained importance in agribusiness research in the 1990's (e.g., Sterns et al., 1998; Mugera and Bitsch, 2005; Fleming et al., 2018; Zhong et al., 2018) as they serve to explore complex agribusiness problems. The present approach can be defined as an instrumental case study. Within an instrumental case study, the researcher intents to refine theory or gain insights into an issue by analyzing commonalties and differences related to the topic (Stake, 1995).

Thirty farm managers from five EU countries namely Germany, Italy, Spain, Slovenia, and the Czech Republic (Table 1) going through a succession process as a successor were included in the study. These countries were chosen as they represent Southern, Eastern and Western European countries, which are different in farm size and economic situation. The interviewees were mostly male, but included three female managers from Italy with differing agricultural specializations, including crop production, production of fruit and vegetables, apiculture, cheese production, and animal husbandry. Succession is a particularly sensitive topic, where emotions and confidential personal and professional experiences and perceptions are shared. Therefore, a qualitative research approach is suitable, because this approach allows researchers to obtain answers to questions of a sensitive nature (Corbin and Morse, 2003; Dickson-Swift et al., 2009).

The case study participants were identified through contacts in each participating country who work as consultants for succession processes in farm family business. The contacts recommended several farm families that went through a succession process or are about to complete the process. From the pool of contacts, participants were chosen according to their willingness to provide access and fully share their experiences. Due to the sensitive nature of the topic further specification in the sampling approach was not possible.

Since farm managers are in charge of a variety of duties and often have a tight time schedule, the managers were provided with a questionnaire, which contained 10 open questions where managers were able to respond in their own words. The answers provided for each question were half a page to one page long. The open questions allowed that the managers freely share their opinions and experiences of the succession process, and their relationships with the predecessor.

Relational as well as behavioral questions are always prone to socially desirable answers. Social desirability describes the tendency of people to answer questions in a socially acceptable way. This behavior results from the basic need of people to orient themselves towards politically correct answers, which appears to be more desirable with regard to the topic of the investigation. People want to present themselves in a positive light. In order to mitigate the bias, critical questions were phrased more indirect or turned into a positive context. This included asking about the common situation instead of a personal situation, or presenting the problem in manner that the interviewee advises on a question. As the questions were presented in a self-completion mode there is no social pressure coming from an interviewer. In addition this avoided a coordination challenge concerning interview training and potential interview affects such as iceberg effect, paternalism effect, back-coupling effect, and catharsis effect. One drawback of the chosen procedure is the potential limit of a written response; however the open-ended questions still allow getting information about feelings and situations, as the nature of the question does not allow to respond with only one word.

All documents were translated into English. The text documents were analyzed by inductive qualitative content analysis. During the analysis process, raw text was systematically broken down into meaningful elements and common themes were extracted. This was achieved through constant comparison and contrasting of the material. Ultimately, process and relationship patterns were identified. The constant contrast and comparison method is particular suitable for a country comparison, because commonalities and differences in the secession are emphasized. This process of qualitative content analysis was carried out using the software package Atlas.ti 8, which allows for systematic analysis of documents.

Along with the qualitative research approach, a literature review was conducted using succession models, family business, agriculture, conflict, as keyword combinations. The databases Scopus, PubMed, Science Direct and Google Scholar facilitated the search.

\section{Results and discussion}

All interviewees indicated that good relationships within their family and even more with their predecessor are essential when going through the succession process. In both horticulture and agriculture, some interviewees reported that they felt well prepared to master the succession process and ultimately take on the business. Others reported that the relationship was rather troubled, and there was little communication and feedback. They reported on conflicts during and after the succession process within the family and with the predecessor (Table 2).

In particular the three female successors reported on a good relationship with their predecessors. They perceived their fathers as guides and mentors on whom they could rely throughout the succession process and afterwards. In contrast to the existing body of literature, none of the female successors indicated that taking on the business strained their relationships with fathers or non-family employees (Vera and Dean, 2005; Nelson and Constantinidis, 2017; Faraudello and Songini, 2018; Nilson and Hytti, 2018). They felt respected by predecessors and employees, and similar to German, Czech, and Slovenian male successors they rather reported on conflicts with siblings in the succession process. The absence of father-daughter conflict can be explained by the fact that the female successors grew up on the farm and were involved in the family farm since their childhood. Further, they went through a suitable agricultural education, which includes apprenticeships and work experience on other farms, as well as university degrees. Mair and Bitsch (2018) indicated that the early farm involvement is an important observation point for the predecessor whether the offspring is a worthy heir; during childhood the potential successors get small tasks and their responsibility grows over time. Predecessors require from their successor, equal skills and education, similar or higher than their own, so they 
TABLE 2. Topics discussed and text excerpts.

\begin{tabular}{|c|c|}
\hline Topic emerged & Text excerpts from interviews \\
\hline \multirow[t]{2}{*}{$\begin{array}{l}\text { Conflicts during and after } \\
\text { the succession process }\end{array}$} & $\begin{array}{l}\text { "There were no problems with my father, we always discussed everything. And up to now, we discuss everything." } \\
\text { (Female successor, Italy, animal husbandry). }\end{array}$ \\
\hline & $\begin{array}{l}\text { "Justice was an important issue for the family, since harmony is at the heart of each person involved. It was not easy } \\
\text { to meet my siblings' demands. However, through the extension agent who supported the succession process, we } \\
\text { managed." (Male successor, Germany, specialty crop production). }\end{array}$ \\
\hline \multirow[t]{2}{*}{$\begin{array}{l}\text { Dealing with generational } \\
\text { problems }\end{array}$} & $\begin{array}{l}\text { "Initially, three generations lived under one roof, where conflicts were escalating. The close proximity even after } \\
\text { work was very problematic, as there were interpersonal problems. Moving to a new house improved the relationship } \\
\text { significantly." (Male successor, Germany, animal husbandry). }\end{array}$ \\
\hline & $\begin{array}{l}\text { "My grandfather and I have different opinions on the farm. I would like to expand the business; my grandfather is } \\
\text { satisfied with the status quo of the farm." (Male successor, Republic of Slovenia, specialty crop production). }\end{array}$ \\
\hline
\end{tabular}

Source: Authors own elaboration.

Note: The inclusion and presentation of original text excerpts is a common practice in qualitative research. Text excerpts are used to support researcher claims, illustrate ideas, present experience and evoke emotion. Choosing text excerpts and quoting requires the researcher respects aesthetics and ethics (Sandelovski, 1994).

can trust that the business will be continued successfully (De Massis et al., 2008; Cabrera-Suárez et al., 2018).

The occurrence of sibling conflict and rivalry is common in succession processes. Conflicts are either related to power, distributing business shares, or pay-off (Vera and Dean, 2005; Avloniti et al., 2014; Bizri, 2016). All case study participants who experienced conflicts with siblings reported on arguments related to legal and financial matters. The interviewees, who did not experience rivalry, assumed that the absence of rivalry among them and their siblings for the succession position can be attributed to different life goals and occupational interests. Another reason could be a response bias, as the case study participants might have wanted to present their family in a positive light.

With regard to conflict, German, Czech, and Slovenian successors reported on generational conflicts within the family or with the predecessor. These case study participants explained how they dealt with "the watchful eye" of their predecessors, generational conflicts as well as the common conflict between the successor's and the predecessor's spouses (Table 2). A generational shadow is the most common form of a post-succession conflict, when predecessors interfere undesirably with the business, after the succession processes is completed. This results from the predecessor's unwillingness or inability to give up the role at the helm of the business (Davis and Harveston, 1999; Sonfield and Lussier, 2009; Chirico and Nordqvist, 2010). Surprisingly, generational conflicts appeared less extreme in cases when the farm was transferred to a grandchild as the successor. The greater age difference and the respective recognition of roles, abilities and experiences had a positive influence on the conflict. These successors indicated that their skill set and experience is complementing the skills of their predecessors, and therefore both parties experienced minor conflicts and rather mutual learning experiences. All case study participants who experienced post-succession conflicts with their predecessors suggested clear role definitions, communication, and consulting could help to overcome or at least improve the issue. No differences were found between horticultural and agricultural successors.

Similar solutions were suggested in the case of daughterin-law-mother-in-law conflicts. In these situations, the successors felt either distraught, because they are in-between the individuals involved in the conflict and usually values both in a comparable way. Open communication, physical distance, role definition, and acknowledgment of experience and consulting can support solving these types of conflicts. Furthermore, balancing work and professional life is suggested.

All case study participants emphasized the importance of production knowledge and business skills. All but one case study participants reported to be satisfied with their agricultural education and that they have comprehensive production, as well as processing knowledge depending on their background. The case study participant, who was not satisfied with production knowledge and skills, admitted that it was not his first choice to take on the family farm, and initially he had actively pursued other career plans. Therefore, this case study participant had good managerial skills, which are also important when taking on the family business, and was not struggling with finance and bookkeeping, which many other participants were. Following De Massis et al. (2008) and Waldkirch et al. (2018), successors must be fully convinced that they want to take on the business, to avoid regrets regarding alternative career opportunities. Participants from each European country involved in the present study indirectly addressed this aspect, as they emphasized work experience in other agricultural enterprises as valuable to make a conscious choice as a successor. All participants emphasized good organizational and analysis skills, communication and leadership skills, self-confidence, patience, and calmness as personal skills that are needed in the succession process and as farm managers.

As shown, there are many transnational similarities when considering the successors' perspectives on taking on the family business. Educational requirements and skills were similar in all countries. The required skills emphasized by the case study participants as well as prior literature correspond to types of skills that are required for any leading position in horticulture and agriculture (Bennett, 2002; Šùmane et al., 2018). Organizational and analysis skills are required to solve specific problems. They can be classified as transferable skills, as they are useful for a broad variety of agricultural business and production tasks. Further self-confidence, patience, and calmness are personal characteristics supportive to the execution of tasks. They are acquired throughout a lifetime and are considered as personal attributes. Bookkeeping, finance, leadership and communication 
are knowledge-based skills, which are acquired through practice and training.

All other findings relate to family conflicts, which also affect the business environment, as family and business are connected through the successor and interactions with the predecessor and family members throughout and after the succession process. As this work is presenting a successor perspective, findings reflect work family border theory (Clark, 2000) rather than the more commonly known three-circle model, which is more process orientated (Gersick et al., 1997; Casper et al., 2018).

\section{Conclusions}

The present case study investigated the succession process from the successor perspective. The study found educational and relational similarities in five European countries (Germany, Italy, Spain, Czech Republic, and Slovenia). The results showed that successful succession requires organizational and analytical skills as well as knowledge-based skills such as communication, management, finance, and law. Also conflict management skills are important. Actors should self-reflect and reflect on the others involved, as they need to interact with each other in both the business and the family. In conflict management, conflict identification and communication is the key. In cases where successor and predecessor are unable to solve the conflict by themselves, they should rely on the service of an extension agent who can act as a mediator. Apart from conflict, extension agents are beneficial along the entire succession process, as they can provide a listening ear and long-term assistance with various problems occurring. Since the predecessor's watchful eye is often a source of conflict in the horticultural and agricultural succession process, and both predecessor and successor usually suffer from generational conflict, the following recommendations may be helpful to prevent the problem:

- The predecessor should schedule a date for retirement, as it provides a clear timeframe for the successor, when the process will be completed.

- In the transition time, the predecessor could take a break from business, for instance vacations, leaving the responsibility to the successor. This allows establishing confidence and trust between both parties, so the successor proves the family business operates appropriately, even without the predecessor. Further predecessor and successor should meet regularly to share their perspectives on the process and the future of the business.

- Predecessor and successor should have distinct roles. Predecessor and successor should not take any actions that undermine their agreed role.

In addition to conflict management, the study showed that there are nearly no differences in the succession process between horticulture and agriculture. Reasons behind this finding may be that boundaries between both professions are not as distinct, as similar organizational, analytical, and knowledge-based skills are required in terms of management and with respect to the succession process. In many European countries, horticulture is considered as a specific part of agriculture.

European horticulture as well as agriculture is rather traditional; both sectors are still dominated by men, however, women increasingly take on important roles in leadership positions. This research topic could be further explored and deepened in agricultural gender studies, were higher num- bers of females are present in the study. The number of female interviewees can be seen as a limit of the present study. Future research should also be dedicated to the challenges women face in agricultural succession, with respect to rivalry with male siblings and other competitors. Another opportunity for future research is to explore the role of trust in the succession process. Up to present, few studies address trust in this context, but it is essential in communication, conflict, throughout the process and afterwards.

\section{Acknowledgments}

The authors gratefully acknowledge funding of the European Commission and the support of all participants and partners of the Erasmus+ project "Farm-Success-2015-1-DE02-KA202-002390" who contributed to data collection.

\section{Conflict of interest}

The authors declare that there is no conflict of interest.

\section{References}

Andersson, T., Carlsen, J., and Getz, D. (2002). Family business goals in the tourism and hospitality sector: Case studies and cross-case analysis from Australia, Canada, and Sweden. Family Business Rev. 15(2), 89-106. https://doi.org/10.1111/j.1741-6248.2002.00089.x.

Avloniti, A., Iatridou, A., Kaloupsis, I., and Vozikis, G.S. (2014). Sibling rivalry: implications for the family business succession process. Int. Entrepreneurship and Manag. J. 10(4), 661-678. https://doi. org/10.1007/s11365-013-0271-6.

Barach, J.A., and Ganitsky, J.B. (1995). Successful succession in family business. Family Business Rev. 8(2), 131-155. https://doi. org/10.1111/j.1741-6248.1995.00131.x.

Barach, J.A., Gantisky, J., Carson J.A., and Doochin, B.A. (1988). Entry of the next generation: Strategic challenge for family business. J. Small Business Manag. 26(2), 49-56.

Barnard, F.L., Akridge, J.T., Dooley, F.J., Foltz, J.C., and Yeager, E.A. (2016). Agribusiness Management (New York, US: Routledge), https://doi.org/10.4324/9781315709420.

Bennett, R. (2002). Employers' demands for personal transferable skills in graduates: A content analysis of 1000 job advertisements and an associated empirical study. J. Vocational Education and Training, 54(4), 457-476. https://doi.org/10.1080/13636820200200209.

Bizri, R. (2016). Succession in the family business: drivers and pathways. Int. J. Entrepreneurial Behavior and Res. 22(1), 133-154. https://doi.org/10.1108/IJEBR-01-2015-0020.

Bjuggren, P.O., and Sund, L.G. (2014). A contractual perspective on succession in family firms: a stakeholder view. Eur. J. Law and Economics 38(2), 211-225. https://doi.org/10.1007/s10657-0129331-6.

Boland, M., Lehman, E., and Stroade, J. (2001). A comparison of curriculum in baccalaureate degree programs in agribusiness management. Int. Food and Agribusiness Manag. Rev. 4(3), 225-235. https://doi.org/10.1016/S1096-7508(01)00083-0.

Boyar, S.L., Maertz Jr., C.P., and Pearson, A.W. (2005). The effects of work-family conflict and family-work conflict on nonattendance behaviors. J. Business Res. 58(7), 919-925. https://doi. org/10.1016/j.jbusres.2003.11.005.

Brandth, B., and Overrein, G. (2013). Resourcing children in a changing rural context: fathering and farm succession in two generations of farmers. Sociologia Ruralis 53(1), 95-111. https:// doi.org/10.1111/soru.12003.

Breton-Miller, I.L., Miller, D., and Steier, L.P. (2004). Toward an integrative model of effective FOB succession. Entrepreneurship 
Theory and Practice 28(4), 305-328. https://doi.org/10.1111/ j.1540-6520.2004.00047.x.

Burton, R.J., and Fischer, H. (2015). The succession crisis in European agriculture. Sociologia Ruralis 55(2), 155-166. https:// doi.org/10.1111/soru.12080.

Byrne, J., Fattoum, S., and Thébaud, S. (2018). A suitable boy? Gendered roles and hierarchies in family business succession. Eur. Manag. Rev. 16(3), 579-596. https://doi.org/10.1111/emre.12298.

Cabrera-Suárez, M.K., García-Almeida, D.J., and De Saá-Pérez, P. (2018). A dynamic network model of the successor's knowledge construction from the resource-and knowledge-based view of the family firm. Family Business Rev. 31(2), 178-197. https://doi. org/10.1177/0894486518776867

Cadieux, L., Lorrain, J., and Hugron, P. (2002). Succession in womenowned family businesses: A case study. Family Business Rev. 15(1), 17-30. https://doi.org/10.1111/j.1741-6248.2002.00017.x.

Calabrò, A., Minichilli, A., Amore, M.D., and Brogi, M. (2018). The courage to choose! Primogeniture and leadership succession in family firms. Strategic Manag. J. 39(7), 2014-2035 https://doi. org $/ 10.1002 /$ smj. 2760

Casper, W.J., Vaziri, H., Wayne, J.H., DeHauw, S., and Greenhaus, J. (2018). The jingle-jangle of work-nonwork balance: A comprehensive and meta-analytic review of its meaning and measurement. J. Appl. Psychology 103(2), 182-214. https://doi.org/10.1037/apl0000259.

Chalus-Sauvannet, M.C., Deschamps, B., and Cisneros, L. (2016). Unexpected succession: When children return to take over the family business. J. Small Business Manag. 54(2), 714-731. https:// doi.org/10.1111/jsbm.12167.

Chirico, F., and Nordqvist, M. (2010). Dynamic capabilities and trans-generational value creation in family firms: The role of organizational culture. Int. Small Business J. 28(5), 487-504. https:// doi.org/10.1177/0266242610370402.

Chiswell, H.M. (2014). The importance of next generation farmers: a conceptual framework to bring the potential successor into focus. Geography Compass 8(5), 300-312. https://doi.org/10.1111/ gec3.12131.

Chiswell, H.M. (2018). From generation to generation: Changing dimensions of intergenerational farm transfer. Sociologia Ruralis 58(1), 104-125. https://doi.org/10.1111/soru.12138.

Chua, J.H., Chrisman, J.J., and Sharma, P. (2003). Succession and nonsuccession concerns of family firms and agency relationship with nonfamily managers. Family Business Rev. 16(2), 89-107. https://doi.org/10.1111/j.1741-6248.2003.00089.x.

Clark, S.C. (2000). Work/family border theory: A new theory of work/family balance. Human Relations 53(6), 747-770. https://doi. org/10.1177/0018726700536001.

Collins, J.D., Worthington, W.J., and Schoen, J.E. (2016). Family business CEO succession: Examining personal retirement expectations. J. Small Business Strategy 26(2), 51-70.

Corbin, J., and Morse, J.M. (2003). The unstructured interactive interview: Issues of reciprocity and risks when dealing with sensitive topics. Qualitative Inquiry 9(3), 335-354. https://doi.org/10.1177/ 1077800403009003001.

Dalpiaz, E., Tracey, P., and Phillips, N. (2014). Succession narratives in family business: The case of Alessi. Entrepreneurship Theory and Practice 38(6), 1375-1394. https://doi.org/10.1111/etap.12129.

Davis, J.H., Allen, M.R., and Hayes, H.D. (2010). Is blood thicker than water? A study of stewardship perceptions in family business. Entrepreneurship Theory and Practice 34(6), 1093-1116. https:// doi.org/10.1111/j.1540-6520.2010.00415.x.
Davis, P.S., and Harveston, P.D. (1999). In the founder's shadow: Conflict in the family firm. Family Business Rev. 12(4), 311-323. https://doi.org/10.1111/j.1741-6248.1999.00311.x.

De Massis, A., Chua, J.H., and Chrisman, J.J. (2008). Factors preventing intra-family succession. Family Business Rev. 21(2), 183-199. https://doi.org/10.1111/j.1741-6248.2008.00118.x.

Dhaenens, A.J., Marler, L.E., Vardaman, J.M., and Chrisman, J.J. (2018). Mentoring in family businesses: Toward an understanding of commitment outcomes. Human Resource Manag. Rev. 28(1), 46-55. https://doi.org/10.1016/j.hrmr.2017.05.005.

Dickson-Swift, V., James, E.L., Kippen, S., and Liamputtong, P. (2009). Researching sensitive topics: Qualitative research as emotion work. Qualitative Res. 9(1), 61-79. https://doi.org/10.1177/ 1468794108098031

Dudek, M. (2016). A matter of family? An analysis of determinants of farm succession in Polish agriculture. Studies in Agric. Economics 118(2), 61-67. https://doi.org/10.7896/j.1613.

Eddleston, K.A., and Kellermanns, F.W. (2007). Destructive and productive family relationships: A stewardship theory perspective. J. Business Venturing 22(4), 545-565. https://doi.org/10.1016/j. jbusvent.2006.06.004.

Eurostat (2016). Agriculture statistics - Family farming in the EU. http://ec.europa.eu/eurostat/statistics-explained/index.php/ Agriculture_statistics__family_farming_in_the_EU (accessed June 7, 2018).

Eurostat (2019). Youth unemployment. https://ec.europa.eu/ eurostat/statistics-explained/index.php/Youth_unemployment (accessed May 9, 2019).

Fahed-Sreih, J., and Zakka, J.S. (2016). Lebanon: Father-daughter succession in family business within a Middle Eastern culture. In Father-Daughter Succession in Family Business (Routledge), p. 6776.

Faraudello, A., and Songini, L. (2018). Women's role in family business: evolution and evidences from a European case study. J. Modern Accounting and Auditing 14(2), 70-89. https://doi. org/10.17265/1548-6583/2018.02.003.

Fausti, S., Erickson, B., Clay, S., Schumacher, L., Clay, D., and Skouby, D. (2018). Educator survey: Do institutions provide the precision agriculture education needed by agribusiness? J. Agribusiness 36(1), 41-63.

Fleming, E., Griffith, G., Mounter, S., Hartmann, M., and Simons, J. (2018). Food value chain coordination in practice: European and Australian case studies of the creation of chain good innovations. Proc. in Food Syst. Dynamics, p. 321-328.

Friedman, S.D. (1991). Sibling relationships and intergenerational succession in family firms. Family Business Rev. 4(1), 3-20. https:// doi.org/10.1111/j.1741-6248.1991.00003.x.

Gagnè, M., Wrosch, C., and Brun de Pontet, S. (2011). Retiring from the family business: The role of goal adjustment capacities. Family Business Rev. 24(4), 292-304. https://doi. org/10.1177/0894486511410688.

Gersick, K.E., Davis, J.A., McCollom Hampton, M., and Lansberg, I. (1997). Generation to Generation: Life Cycles of the Family Business (Boston, Mass.: Harvard Business School Press)

Gherardi, S., and Perrotta, M. (2016). Daughters taking over the family business: Their justification work within a dual regime of engagement. Int. J. Gender and Entrepreneurship 8(1), 28-47. https://doi.org/10.1108/IJGE-11-2014-0044.

Greenhaus, J.H., Collins, K.M., and Shaw, J.D. (2003). The relation between work-family balance and quality of life. J. Vocational Behavior 63(3), 510-531. https://doi.org/10.1016/S00018791(02)00042-8. 
Handler, W.C. (1989). Managing the Family Firm Succession Process: The Next-Generation Member's Experience Ph.D. thesis (Boston: Boston University).

Harrington, B., and Strike, V.M. (2018). Fiduciaries and Family Firms: Integrating the Logics of Commerce and Family. Acad. Manag. Proc. 2018(1), 15364. https://doi.org/10.5465/AMBPP.2018.18.

Harvey, M., and Evans, R. (1995). Life after succession in the family business: Is it really the end of problems? Family Business Rev. 8(1), 3-16. https://doi.org/10.1111/j.1741-6248.1995.00003.x.

Howley, P., Donoghue, C.O., and Heanue, K. (2012). Factors affecting farmers' adoption of agricultural innovations: A panel data analysis of the use of artificial insemination among dairy farmers in Ireland. J. Agric. Sci. 4(6), 171-179. https://doi.org/10.5539/jas.v4n6p171.

Joshi, M., Sinha, A.K., Dixit, S., and Shukla, B. (2018). Transition dilemma in a closely held family business: A case of Excel Transporters. Eur. J. Family Business 8(1), 17-32. https://doi.org/ 10.24310/ejfbejfb.v8i1.4939.

Kidwell, R.E., Eddleston, K.A., and Kellermanns, F.W. (2018). Learning bad habits across generations: How negative imprints affect human resource management in the family firm. Human Res. Manag. Rev. 28(1), 5-17. https://doi.org/10.1016/j.hrmr.2017.05.002.

Klein, S.B. (2000). Family businesses in Germany: Significance and structure. Family Business Rev. 13(3), 157-182. https://doi. org/10.1111/j.1741-6248.2000.00157.x.

Kreiner, G.E., Hollensbe, E.C., and Sheep, M.L. (2009). Balancing borders and bridges: Negotiating the work-home interface via boundary work tactics. Acad. of Manag. J. 52(4), 704-730. https:// doi.org/10.5465/amj.2009.43669916.

Lansberg, I. (1988). The succession conspiracy. Family Business Rev. 1, 119-143. https://doi.org/10.1111/j.1741-6248.1988.00119.x.

Lansberg, I. (1999). Succeeding Generations: Realizing the Dreams of Families in Business (Boston, MA: Harvard Business School Press).

Lee, K.S., Lim, G.H., and Lim, W.S. (2003). Family business succession: Appropriation risk and choice of successor. Acad. of Manag. Rev. 28(4), 657-666. https://doi.org/10.5465/amr.2003.10899446.

Leiß, G., and Zehrer, A. (2018). Intergenerational communication in family firm succession. J. Family Business Manag. 8(1), 75-90. https://doi.org/10.1108/JFBM-09-2017-0025.

Leonard, B., Mahon, M., Kinsella, A., O’Donoghue, C., Farrell, M., Curran, T., and Hennessy, T. (2017). The potential of farm partnerships to facilitate farm succession and inheritance. Int. J. Agric. Manag. 6(1), 4-19.

Lobley, M., Baker, J.R., and Whitehead, I. (2016). Farm succession and retirement: some international comparisons. J. Agric., Food Systems, and Community Developm. 1(1), 49-64. https://doi.org/10.5304/ jafscd.2010.011.009.

Lockamy, A., Carson, C.M., and Lohrke, F.T. (2016). An evaluation of key determinants preventing intra-family business succession. J. Family Business Manag. 6(1), 64-80. https://doi.org/10.1108/ JFBM-01-2015-0002.

Mair, S., and Bitsch, V. (2018). Succession in horticultural family businesses: The role of socialization and communication. Int. J. Food System Dynamics 9(3), 279-288.

Michel, A., and Kammerlander, N. (2015). Trusted advisors in a family business's succession-planning process - An agency perspective. J. Family Business Strategy 6(1), 45-57. https://doi.org/10.1016/j. jfbs.2014.10.005.

Mugera, A.W., and Bitsch, V. (2005). Managing labor on dairy farms: a resource-based perspective with evidence from case studies. Int. Food and Agribusiness Manag. Rev. 8(3), 79-98.
Nelson, T., and Constantinidis, C. (2017). Sex and gender in family business succession research: A review and forward agenda from a social construction perspective. Family Business Rev. 30(3), 219241. https://doi.org/10.1177/0894486517715390.

Nilson, H., and Hytti, U. (2018). Moving between visibility and invisibility: Understanding social and family business spheres. In Women in Business Families (Routledge), p. 113-124. https://doi. org/10.4324/9781315206295-7.

Nuthall, P.L., and Old, K.M. (2017). Farm owners' reluctance to embrace family succession and the implications for extension: the case of family farms in New Zealand. J. Agric. Education and Extension, 23(1), 39-60. https://doi.org/10.1080/1389224X.2016.1200992.

Potter, C., and Lobley, M. (1996). Unbroken threads? Succession and its effects on family farms in Britain. Sociologia Ruralis 36(3), 286306. https://doi.org/10.1111/j.1467-9523.1996.tb00023.x.

Riley, M. (2016). Still Being the 'Good Farmer': (Non-)retirement and the preservation of farming identities in older age. Sociologia Ruralis 56(1), 96-115. https://doi.org/10.1111/soru.12063.

Rousseau, M.B., Kellermanns, F.W., Zellweger, T.M., and Beck, T. (2019). Relationship conflict, family name congruence, and socioemotional wealth in family firms. https://www.alexandria.unisg.ch/254569/1/ Relationship\%20Conflict\%20and\%20Valuation.pdf (accessed June 24 , 2018). Forthcoming in Family Business Review.

Samei, H., and Feyzbakhsh, A. (2015). Predecessors competency framework for nurturing successors in family firms. Int. J. Entrepreneurial Behavior and Res. 21(5), 731-752. https://doi. org/10.1108/IJEBR-02-2015-0043.

Sandelowski, M. (1994). Focus on qualitative methods. The use of quotes in qualitative research. Res. in Nursing and Health 17(6), 479-482. https://doi.org/10.1002/nur.4770170611.

Sharma, P. (2004). An overview of the field of family business studies: Current status and directions for the future. Family Business Rev. 17(1), 1-36. https://doi.org/10.1111/j.1741-6248.2004.00001.x.

Sharma, P., and Irving, P.G. (2005). Four bases of family business successor commitment: Antecedents and consequences. Entrepreneurship Theory and Practice 29(1), 13-33. https://doi.org/ 10.1111/j.1540-6520.2005.00067.x.

Sonfield, M.C., and Lussier, R.N. (2009). Non-family-members in the family business management team: a multinational investigation. Int. Entrepreneurship and Manag. J. 5(4), 395-415. https://doi. org/10.1007/s11365-009-0109-4.

Stake, R.E. (1995). The Art of Case Study Research (Thousand Oaks, California, US: Sage).

Steiger, T.L., Eckert, J., Gatrell, J., Reid, N., and Ross, P. (2011). Cultivating narratives: Cultivating successors. J. Agric., Food Systems, and Community Developm. 2(2), 89-105. https://doi.org/10.5304/ jafscd.2012.022.012

Sterns, J.A., Schweikhardt, D.B., and Peterson, H.C. (1998). Using case studies as an approach for conducting agribusiness research. Int. Food and Agribusiness Manag. Rev. 1(3), 311-327. https://doi. org/10.1016/S1096-7508(99)80002-0.

Strike, V.M., Michel, A., and Kammerlander, N. (2018). Unpacking the black box of family business advising: Insights from psychology. Family Business Rev. 31(1), 80-124. https://doi. org/10.1177/0894486517735169.

Šūmane, S., Kunda, I., Knickel, K., Strauss, A., Tisenkopfs, T., des Ios Rios, I., and Ashkenazy, A. (2018). Local and farmers' knowledge matters! How integrating informal and formal knowledge enhances sustainable and resilient agriculture. J. Rural Studies 59, 232-241. https://doi.org/10.1016/j.jrurstud.2017.01.020. 
Tagiuri, R., and Davis, J.A. (1992). On the goals of successful family companies. Family Business Rev. 5(1), 43-62. https://doi. org/10.1111/j.1741-6248.1992.00043.x.

Umans, I., Lybaert, N., Steijvers, T., and Voordeckers, W. (2018). Succession planning in family firms: family governance practices, board of directors, and emotions. Small Business Economics 54, 189-207. https://doi.org/10.1007/s11187-018-0078-5.

Vera, C.F., and Dean, M.A. (2005). An examination of the challenges daughters face in family business succession. Family Business Rev. 18(4), 321-345. https://doi.org/10.1111/j.17416248.2005.00051.x

Waldkirch, M., Nordqvist, M., and Melin, L. (2018). CEO turnover in family firms: How social exchange relationships influence whether a non-family CEO stays or leaves. Human Res. Manag. Rev. 28(1), 56-67. https://doi.org/10.1016/j.hrmr.2017.05.006.

Welter, F., Haag, K., and Achtenhagen, L. (2017). The role of gender in family-business research: A systematic review of the literature. In Women Entrepreneurship in Family Business, V. Ratten, L.P. Dana, and V. Ramadani (eds.) (New York, US: Routledge).

Zhong, Z., Zhang, C., Jia, F., and Bijman, J. (2018). Vertical coordination and cooperative member benefits: Case studies of four dairy farmers' cooperatives in China. J. Cleaner Production 172, 2266-2277. https://doi.org/10.1016/j.jclepro.2017.11.184.

Received: Nov. 29, 2018

Accepted: May 12, 2019

Addresses of authors:

Stefan Mair ${ }^{1, *}$ and Meike Rombach ${ }^{2}$

1 Technical University of Munich, Chair Group of Economics of Horticulture and Landscaping, Alte Akademie 16, 85354 Freising, Germany

2 Lincoln University, Land Management and Systems, P.O. Box 85084, Lincoln 7647, Christchurch, New Zealand

* Corresponding author; E-mail: stefan.mair@tum.de Tel.: +49 8161 71-2541; Fax: +49 8161 71-2530 